\title{
Chapter 5 Examining the Levels of Reasoning Used by Urban Elementary Black Girls Engaging in Technology- Enhanced Inquiry
}

\author{
Gayle A. Buck \\ Indiana University, USA \\ Nicole Beeman-Candwallader \\ Project Lead the Way, USA \\ Amy 'Trauth-Nare \\ University of Deleware, USA
}

\begin{abstract}
Technological tools such as interfaces, sensors and proberware are increasingly prevaleme in science classrooms. With increased prevalence comes a need to improve the research base on how to use

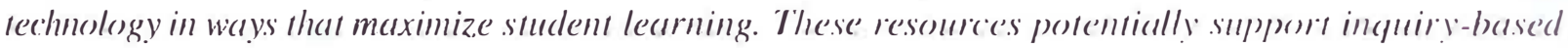

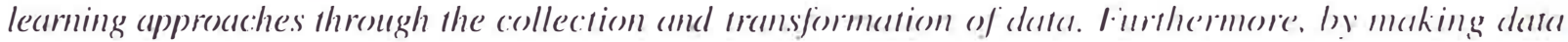
trends evident, these technologies have the potential to support construction of scientific applantationts and complex reasoning. The purpose of this study was an analyze the levels of reasonting a displayed by African American girls engaged in technology-enhanced inchuiry so as to bether anderstand the extent to which technology can support scientific literacy. Our results indicated modest gains in the girls" ability 10 display data and connect data trends as scientific phenomenon. We helieve thent stud sing the experi-

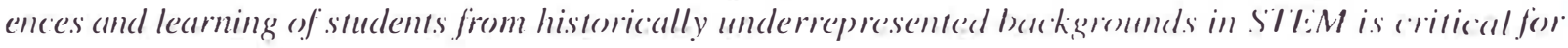
ensuring equitable educational experiences and access to STEM-related propessions.
\end{abstract}




\section{INTRODUCTION}

Black girls have historically performed lower on a number of academic measures when compared to girls as a whole, according to a report released by the National Women's Law Center and the NAACP Legal Defense and Education Fund (Smith-Evans \& George, 2014). Black girls continue to encounter deeply embedded racial and gender stereotypes and harsher disciplinary actions for non-conforming behaviors such as expressing their opinions. These girls, disproportionately concentrated in under resourced schools and less likely to be taught by highly qualified teachers, often have limited access to rich, meaningful science, technology, engineering and mathematics (STEM) instruction (Brickhouse, Lowry, \& Schulz, 2000; Carlone, 2004). They are often overlooked for, or discouraged from taking advantage of, STEM learning opportunities by educators holding stereotypical beliefs about the girls' abilities or interests. With less access to high quality science learning opportunities that lead to postsecondary STEM education and higher wage professions, Black girls face long-term socioeconomic effects (Smith-Evans \& George, 2014).

Maintaining the status quo in under resourced schools located in low socioeconomic (SES) neighborhoods reinforces the achievement gap for Black girls, especially in the face of major learning standards reforms such as the Common Core State Standards for Mathematics (National Governors Association Center for Best Practices, 2010) and the Next Generation Science Standards (NGSS Lead States, 2013) for science and engineering. In particular, science education reform efforts (National Research Council, 2012; NGSS Lead States, 2013) emphasize scientific practices such as analyzing and interpreting data; using mathematics, information and computer technologies and computational thinking; and constructing explanations of scientific phenomena.

To be successful in STEM, students increasingly need to perform at higher levels of complex reasoning, such as analyzing empirical evidence and generating arguments and explanations (NRC, 2012). Yet, the situation in schools with high percentages of Black girls continue to engender pedagogical approaches that do not promote student ownership for learning or the development of complex reasoning skills (Songer, Lee \& Kam, 2002). In addition, the Black girls in these low SES schools continue to be less likely to use technology for creativity, problem-solving, or higher-order thinking required in science inquiry (Songer et al., 20(02).

As postsecondary science educators, we were invited to support one urban school district's efforts to establish an effective STEM learning environment for students at an all-girls elementary STEM academy. The partnership involved securing science equipment, such as data collection technologies, establishing science labs, and providing ongoing professional development to teachers for science inquiry instruction. To better understand the influence of the partnership on science learning, we examined the girls' efforts in collecting and analyzing data, as well as their ability to reason and generate explanations as they engaged in STEM inquiry activities. This case study was guided by the following research questions:

1. To what extent did the girls use technology proficiently to collect and represent data during inquiry?

2. What categories of complex reasoning were displayed in the girls' interpretations of data collected during technology-enhanced inquiry?

a. Did the categories of complex reasoning change over subsequent encounters with technology? If so, how? 
Examining the Levels of Reasoning Used by Urban Elementary Black Girls

\section{BACKGROUND}

\section{Technology-Enhanced Inquiry}

Technology-enhanced inquiry has been shown to promote science learning (Lee, Linn, Varma, \& Liu, 2010; Harskamp, Suhre, \& VanStreun, 2000; Kwon, 2002; Parr, Jones, \& Songer, 2004; Webb, 2008; Zucker, Tinker, Staudt, Mansfield, \& Metcalf, 2008). Linn (2003) described important trends with regard to the use of technology in science education in the past few decades. First, technologies such as probeware and interfaces have become more tailored to specific topics, audiences, and disciplines and these technologies have become more customizable to suit particular users. Linn contended that with improvements to curricular programs that incorporate data collection technologies, students' performance and experiences also improve exponentially. Furthermore, the studies by Campbell et al., (2015) and Wilson et al. (2010) presented data that suggest the use of technology-enhanced instruction has more dramatically positive effects on the student achievement of non-white students and students with low socioeconomic status, which demonstrates the potential for reducing the achievement gap. Many data collection technologies used in contemporary science and mathematics classrooms are relatively inexpensive compared to their precursors (Kwon, 2002). As a result, these technologies are promising for implementation in schools in underserved and low SES communities. Furthermore, data collection technologies tend to be better tailored to classroom use than computers, which in turn influences the ways in which these technologies can be incorporated into instruction (Krajcik, Marx, Blumenfeld, Soloway, \& Fishman, 2000).

Owing to increased implementation in classrooms, the role of data collection technologies on students' learning is of rising interest to the science education research community. Lee et al. (2010) found students were more likely to develop integrated understanding of science concepts from technologyenhanced inquiry units than from typical instructional methods. Parr et al. (20)(4) showed the effectiveness of hand-held data collection technologies and software for facilitating student observations of animal biodiversity in elementary schoolyards. Analysis of data logs indicated students' ability to notice a range of animal sightings beyond that of live animals, such as animal tracks, signs, smell, or sounds. Kwon (2002) explored the effect of calculator-based ranger (CBR) devices on middle school students' ability to interpret, model, and transform graphical information of physical phenomena. Students used the CBRs to collect real-time data on distance, time, and velocity. Using pre/post-implementation of Graphing Interpretation Skill Test (GIST) (McKenzie \& Padilla, 1986), Kwon found significant differences in graphing ability of students using CBR technology when compared to students in traditional lecture-style science classes. Using word problem prompts, Mitchemore and Cavanagh $(20()())$ investigated how students interpret linear and quadratic graphs on a graphing calculator screen. They found students lacked attention to scale and had difficulty connecting the graph to its symbolic representation. In a $10^{\text {th }}$ grade mathematics class, Harskamp et al. (2000) compares students who used graphing calculators with those who did not. They found the more time students spent using graphing calculators, the more they used graphical strategies to solve problems. Zucker et al. (2008) studied the impact of their Technology Enhanced Elementary School Science II project that included computer and probeware to support inquiry-based units for grades 3-8. They found students benefitted from the incorporation of sensors and probeware (e.g., temperature, pressure) into curriculum units dealing with science topics where graphs are critical to conceptual learning. Overall, this set of research has demonstrated the benefits of technology-enhanced data collection in regards to student outcomes. 


\section{Examining the Levels of Reasoning Used by Urban Elementary Black Girls}

To further support this set of individual research studies, three reviews, Kastberg and Leatham (2005), Thornton (2008) and Forgas, Vale and Ursisi (2010) synthesized findings of studies that specifically examined the use of graphing calculators and data collection technologies. A key finding from Kastberg and Leatham (2005) was that increased access of graphing calculators in schools did not necessarily translate to increased use by students. This finding indicates the need for teacher investment in incorporating graphing calculators into instruction. Thornton's (2008) review indicated students make substantial gains from physics curricula that utilize real-time data collection in an activity-based environment. Forgasz et al. (2010) focused on literature related to gender and equity issues when implementing technology in mathematics classrooms. They reported that in studies conducted in classrooms with mostly high SES students, participants were more likely to hold gender-stereotyped views of computer use on learning. By contrast, in classrooms with mostly low SES students, such gender stereotypes regarding technology were challenged, due in part to the novelty of such resources in those classrooms. By highlighting inherent complexities of technology-enhanced inquiry, these reviews also problematize the individual studies noted earlier by providing evidence that questions the benefits of technology-enhanced data collection with regard to student outcomes.

There are a number of educational studies that examined the use of web-based technologies in science classrooms. Specifically, these studies focused on the integration of web data, software, and tools into science teaching and learning. While not specifically related to the use of data collection technologies, these studies provide valuable insights regarding the use of technology in science classrooms. Songer, Lee, and $\mathrm{Kam}(20) 2$ ) documented patterns in student learning during technology-rich, inquiry science; they found students made significant gains in learning, but constraints such as lack of computer time and reliable internet connections hindered their ability to fully engage in science concepts. In a follow-up study, Lee and Songer (20)3) examined the impact of collecting of the real-time, web-based weather data on students' learning. They found that when students were able to relate forecasting situations to real-time weather data, they were better able to provide detailed scientific explanations. Krajcik et al. $(20)(0)$ examined the impact of project-based units taught in conjunction with Investigators' Workshop, a computational tool intended to support the development of data collection, visualization and analysis. Based on pre-/post-tests designed to match the district's curriculum standards, student performance showed improvement across implementation of all projects.

To summarize, two consistent themes were identified in this set of research on technology-enhanced inquiry in science classrooms. First, nearly all studies revealed benefits of "real-time" data collection and analysis with regard to students' learning. Specifically, such technologies afford rapid, efficient graphical representation of data related to the physical phenomenon under investigation. Second, owing to the usage of technology such as graphing calculators, some of the burden of technical/procedural aspects of computational tasks is removed. As a result, students have more time to consider the meaning and relationship of data to the phenomenon, thus they have the capacity to develop deeper and more connected science conceptions. As Kastberg and Leatham (2005) cautioned, however, simply having access to data collection technologies does not necessarily mean those technologies are being used effectively in classroom instruction. Unfortunately, few studies have focused on uses of data collection technologies in K-12 science classrooms. In addition, few studies directly correlate the use of data collection technologies to students' skills for generating, representing and interpreting data. For example, little is known about the ways in which data collection technologies afford or hinder students' interpretations of data. As technology becomes increasingly prevalent both inside and outside the classroom, we need a better understanding of how data collection technology promotes or undermines students' opportuni- 
Examining the Levels of Reasoning Used by Urban Elementary Black Girls

ties to learn science (Forgasz et al., 2010). Our research extends upon prior studies by examining the benefits of utilizing of technology-enhanced data collection tools on low SES girls' ability to effectively collect, analyze and interpret data.

\section{Data Interpretation and Complex Reasoning}

Complex reasoning is the ability to analyze and interpret empirical data and formulate explanations from evidence (Songer \& Gotwals, 2004). Complex reasoning differs from declarative knowledge in that complex reasoning requires students to understand the connections of claims and evidence to underlying science concepts (Songer, 2000). Tytler and Peterson (2003) showed that children as young as seven can distinguish between competing explanations and can design investigations to test them. Complex reasoning is most effectively developed in the context of authentic science inquiry, where students can build explanations from data as well as develop an understanding of underlying science concepts (Chinn \& Malhotra, 2002).

Several studies have described the levels of reasoning among urban students engaged in curricula interventions. For instance, Songer (2000) described the outcomes of a systemic curricular and assessment program on biodiversity implemented in grades 4-7 in an urban school district. Data indicated students in experimental cohorts significantly differed from control cohorts in their ability to develop hypotheses and predictions, interpret data and formulate scientific explanations from evidence. This study suggests increasing the ability of students to engage in complex reasoning is fostered by carefully designed curricular and assessment programs that specifically scaffold such skills. Songer and Gotwals (2004) showed students who engaged in an 8-week inquiry unit significantly increased in their ability to formulate scientific explanations from evidence on scaffolded assessment tasks. Songer, Kelcey, and Gotwals (2009) suggested using learning progressions as templates for organizing sequences of lessons in curricular units that would scaffold increasingly complex reasoning by students. Dolan and Grady (2010) studied inquiry in high school classrooms and found students displayed complex scientific reasoning about the meaning of data, the connections of data to research questions, how to effectively communicate findings when they were able to conduct their own investigations.

With regard to data analysis and interpretation, the majority of science education studies have focused on understanding how to better support students' skill development in data-related science practices (Bowen \& Roth, 2003, 2005; Bencze \& Bowen, 2007). Roth et al. (1998) found that students' graphic representations became increasingly elaborate over the course of 10 weeks, with increasing experiences with open-inquiry and data they collected cascaded. Roth (1996) sought to understand the role the openinquiry context takes among $8^{\text {th }}$ grade students who did not participate in field studies. Both field study and non-field study groups were presented with similar storied word problems that presented data. The non-field study groups had a less difficult time completing the word problems, but the field studies group was far more capable of producing defensible arguments their responses to word problems. Wu and Krajcik (2006) used a case study to characterize the inscriptional practices of seventh graders, particularly their use of data tables and graphs, during an 8-month instructional unit. They found teacher scaffolding was critical for students in learning how to collect data, construct graphs, and interpret data.

In sum, the research shows that the more students engage in their own, open-ended inquiry investigations, the more supported they will be in developing sophisticated data collection, inscription, and analysis skills. Also, opportunities to collaborate and discuss are critical to the development of skills related to 


\section{Examining the Levels of Reasoning Used by Urban Elementary Black Girls}

data inscription and interpretation. Our research extends upon prior studies by exploring the factors that influence urban Black girls' ability to effectively analyze and interpret data during guided inquiry.

\section{An Imperative to Include Research on Elementary Black Girls}

Scientific practices are used to establish, extend and refine our current understandings of the world (NRC, 2012). Engaging in these practices helps students to understand how scientific knowledge develops, makes that knowledge more meaningful, and embeds it more deeply into their worldview. Research has shown technology-enhanced instruction that engages students in the scientific practices can have a positive impact on the depth of students' science understandings (NRC, 2012; Thornton, 2008; Zucker et al., 2008). Clearly, understanding students' abilities to use technology to collect, analyze and interpret empirical data and formulate explanations is important in science education and studies are increasingly advancing our understandings in this regard. Although this research has done much to increase our understanding of elementary children's science and technology-based experiences, it has not gone far enough. Very few inquiries in this area consider gender, race and SES. Some question the value of research that focuses the educational experiences of one specific group of students when all students need attention; however, an equitable science education demands that we understand the experiences of all students and do not assume the experience of the majority speaks for all (American Association of University Women Educational Foundation, 1999). Research has shown that some of the claims for elementary children in science and technology are not true for children of all situations and raises critical questions in regards assuming the applicability of research findings (e.g., Fordham, 1993; Pringle, Brkich, Adams, West-Olatunii \& Banks, 2012; Rollock, 2007)

Black girls' from low SES communities are uniquely affected by school experiences. For example, Rollock (2007) demonstrated that silencing is critical to understanding the often-ignored Black females, as much of the focus on achievement gaps tend to highlight only their male counterparts. This silencing may explain why Black girls often adopt negative academic strategies such as underperforming and selecting lower level courses to avoid negative interactions (Fordham, 1993). However, there is also research that raises questions about whether these findings are only a reflection of Black girls or the educational settings of which they are a part. Pringle, Brkich, Adams, West-Olatunii and Archer-Banks (2012) found educators who hold stereotypes of girls informed by race and gender often steer female students away from STEM courses. Furthermore, significant differences in class, ethnicity, and gender have made the distribution of resources, such as technology-based data collection instruments, a major contributing factor to differential success among groups of learners (Barton, 2007). The teachers in schools with a substantial proportion of students from low SES and/or minority backgrounds frequently reported a lack of the materials necessary to teach science (Smith-Evans \& George, 2014). Findings such as these raise questions whether gendered relationships are influenced by the individual student or overall school experience (Chavous, Rivas-Drake, Smalls, Griffin \& Cogburn, 2008). These emerging findings enhance our understanding of the factors that can negatively influence efforts to reduce the achievement gap in minority, urban, and gendered groups, an understanding that led us to question any preconceived notions we may have held about the unique educational experiences of these girls. Realizing such differences leads to an imperative to assure a research base that includes finding generated from research on Black girls in low SES school districts.

The existing gap in K-12 STEM achievement for Black girls leads to fewer opportunities in postsecondary education and STEM professions. While women make up 24 percent of the STEM workforce, only 
2 percent of this population is Black (Economics and Statistics Administration, 2011). The challenges inherent in advancing the success of Black girls in STEM are deeply rooted in the ongoing struggle for racial, class, and gender equity. Straying from a deficit model to one of understanding and empowering non-mainstream students will foster a attention to the need to provide adequate opportunities to diverse students tend so they can excel in science (Tal, Krajcik, \& Blumenfeld, 20(06). Our work extends upon prior studies by examining the experiences of urban elementary Black girls as they engaged in technology-enhanced inquiry.

\section{METHOD}

\section{Methodological Approach}

To best understand the levels of complex reasoning of the urban elementary Black girls during technology-enhanced scientific instruction, an exploratory case study design was utilized (Creswell, 2002). A case study is defined as an exploration of a "bounded system" over time through detailed, in-depth data collection involving multiple sources of information (Creswell, 1998). Case studies are particularly appropriate for understand the details and complexity of a situation (Stake, 1995).

\section{Case}

The single case examined in this study was the sixth-grade Black girls attending an all-girl elementary academy in a large urban district in the Midwest. Of the 350 girls that attend this academy, the majority live in public housing developments close to the school. The student population is $99 \%$ Black and 1\% Multiracial, and $88 \%$ qualify for free lunch. Participants in this study included 41 sixth grade Black girls. It should be noted, however, that not all 41 girls participated in every lesson. The number of girls who took part in any single lesson is noted in the findings below. The research team worked with the teachers to assist them in creating lessons that both addressed standards and used technology-enhanced instruction. An individual from the research team also supported the implementation of the lessons during instruction, aiding in making necessary curricular adjustments and assisting in orienting students to the graphing calculators and data collection probeware.

Each lesson incorporated TI-73 graphing calculators (Texas Instruments, 2011) with CBL data collection units and Vernier probeware sensors. This technology was intended to support data collection and analysis during inquiry and facilitate students' interpretations of complex data sets, while building on conceptual understandings of temperature, seasons, and weather. These topics were selected by the teachers in an effort to address the state science standards as well as the school district's curriculum expectations. An overview of the relevant standards is provided in Table 1. During the time of this study, the teachers were also expected to address the topics in a chapter on weather in the district's adopted science textbook. The lessons were created from adapted activities from Volz $(20(0))$ and Johnson, DeMoss, \& Sorensen (2003). An initial decontextualized activity on collecting temperature data, graphing data and interpreting results was used to address the prerequisite knowledge of the scientific process and technological skills necessary to engage in subsequent inquiry-based lessons on seasonal light and temperature changes, the capacity of sunglasses to block UVB radiation, air particulates, and relative humidity. In all lessons, students developed questions from prior knowledge and initial explorations. 
Examining the Levels of Reasoning Used by Urban Elementary Black Girls

Table 1. Listing of State Science Standards Addressed in Lessons

\begin{tabular}{|c|c|}
\hline Type of Standard & Standard \\
\hline Process Standards & $\begin{array}{l}\text { 1. Make predictions and develop testable questions based on research and prior knowledge, } \\
\text { 2. Plan and carry out investigations-often over a period of several class lessons-as a class, in small } \\
\text { groups or independently. } \\
\text { 3. Collect quantitative data with appropriate tools and technologies and use units to label numerical } \\
\text { data. } \\
\text { 4. Incorporate variables that can be changed, measured or controlled, } \\
\text { 5. Use the principles of aceuracy and precision when making measurements, } \\
\text { 6. Test predictions with multiple trials, } \\
\text { 7. Keep accurate records in a notebook during investigations, } \\
\text { 8. Analyze data, using appropriate mathematical manipulation as required, and use it to identify } \\
\text { patterns. Make inferences based on these patterns. } \\
\text { 9. Compare the results of an experiment with the prediction, } \\
\text { 1-0. Conmunicate findings through oral and written reports by using graphs, charts maps and models. }\end{array}$ \\
\hline Content Standards & $\begin{array}{l}\text { Demonstrate that the seasons in both hemispheres are the result of the inclination of the earth on its } \\
\text { axis, which causes changes in sunlight intensity and length of day. }\end{array}$ \\
\hline
\end{tabular}

Then, they designed experiments, used technology-enhanced data collection tools, tabulated their quantitative data in tables and applied their understanding of related science concepts during interpretation of data trends and infer about their significance. With the exception of the first lesson, students were required to produce graphs to appropriately represent data in all lessons. In Lessons 4,5 , and 6 students were expected to do simple mathematical calculations. Writing prompts and classroom questioning by the teachers guided students' written interpretations. Table 2 provides an overview of the lessons in sequence, along with the goals of the lessons and technology employed.

Table 2. Overview of lessons using TI-73 calculator; CBL collection unit and corresponding Vernier sensor(s). Lessons included adapted activities from Volz, (2000) and Johnson, DeMoss, \& Sorensen (2003).

\begin{tabular}{|c|c|c|}
\hline Lesson & Learning Goal(s) & Sensor \\
\hline Temperature & Become familiar with inquiry skills and technology. & temperature \\
\hline Seasons Parı I & $\begin{array}{l}\text { Build and reinfore conceptual understanding of the effect of the tilt of Earth's axis } \\
\text { on its seasons. } \\
\text { Collect temperature data from various places on a globe with light directed at it } \\
\text { simulating the Sun. }\end{array}$ & temperature \\
\hline Seasons Part 2 & $\begin{array}{l}\text { Reinforce understanding of relationship between light and temperature in } \\
\text { producing, seasonal changes. } \\
\text { Develop and implement scientific investigations on the relationship between light } \\
\text { and temperature. }\end{array}$ & temperature \\
\hline UVB & $\begin{array}{l}\text { Build and reinforec conceptual understanding of UVB. } \\
\text { Gather data about the amount of UVB light that passes through sunglasses. }\end{array}$ & UVB \\
\hline Air Pollution & $\begin{array}{l}\text { Build and reinforce conceptual understandings of air pollution. } \\
\text { Draw inferences about collected air particulates from various sites/limes. }\end{array}$ & light \\
\hline Relative humiclity & $\begin{array}{l}\text { Build and reinfore conceptual understanding of relative humidity. } \\
\text { Calculate relative humidity levels in various sites on school grounds. }\end{array}$ & tenperature \\
\hline
\end{tabular}




\section{Data Sources and Analysis}

Data were collected over the course of the six lessons. Each of these class sessions was video and audiorecorded. The girls' written graphic representations and responses to prompts from each of the lessons was also collected and analyzed. Follow-up interviews with the girls were also conducted and recorded.

Content analysis (Ary et al., 2006; Stemler, 2001) was conducted using a priori categories to code: students' written data, audio data from focus groups during class, and transcripts of interviews with the students. Dolan and Grady (2010) described "an analytic tool for recognizing when students engage in complex reasoning during teaching by inquiry" (p. 32). Dolan and Grady situated their study in the context of high school science. The offered a continuum of levels of complexity in reasoning: least, somewhat, more, and most complex. By their definition, most complex reasoning reflects, "the depth of reasoning associated with the work of research scientists" and least "when information is provided to students rather than gathered or reasoned by them" (p. 38). We modified their matrix, using categories of cognitive processes that fit with the intended goals of the inquiry lessons (see Table 2). We found this tool offered us the capacity to extricate nuances among the complexity in students' reasoning. Often, students demonstrated more than one category of complexity. For example, the data in Table 3 were extracted from analysis of students' notebooks, where we analyzed complexity of reasoning of both graphic representations and written explanations. This particular student's graphic representations fell in both the least complex and more complex categories. She included multiple forms of graphic representation, which categorized them as more complex, however, many were copied directly from the calculator, or were incomplete to the point where they were incomprehensible, putting them in the least complex category. Her written explanations fell in both the somewhat complex and more complex categories. She did defend her findings, but did not extend data back to the research question explicitly. She wrote what surprised her about the data, but not how or why. The student wrote, "No, my results were not [what we] expected, because winter turned out to be a little higher... When we moved the globe around the light bulb, the temperatures started to change." (science notebook, 3-12-10) This student's responses are typical in regards to the multiple levels of complexity present.

\section{FINDINGS}

\section{To What Extent did the Girls use Technology Proficiently to Collect and Represent Data During Inquiry?}

To understand the extent to which the girls used technology proficiently to collect and represent data, we analyzed the data tables and graphs in girls' written documents. A summary of results is shown in Table 4. In general, the girls showed an increase across the lessons in their ability to organize and represent data appropriately in tabular form. By Lesson 6, all girls produced a data table in their written documents. They also became more proficient in their ability to produce appropriate graphs to represent data. In Lesson 2, only 23 of 35 girls correctly identified the independent and dependent variables from their investigations and accurately plotted them on the $x$ - and $y$-axis, respectively. By Lesson 6 , more girls were producing accurate graphs, with 28 of 29 girls doing so. Finally, there was an increase in the girls' ability to accurately calculate using data collected from investigations. Although the girls were only required to complete mathematical calculations in last three lessons, by Lesson $6,80 \%$ of them were able to complete these calculations correctly. 
Examining the Levels of Reasoning Used by Urban Elementary Black Girls

Table 3. Modified version of the matrix developed by Dolan \& Grady (2010) for evaluating students' complexity of reasoning

\begin{tabular}{|c|c|c|c|c|}
\hline \multirow[t]{2}{*}{ Cognitive process } & \multicolumn{4}{|c|}{ Complexity of Reasoning on Scientific Tasks } \\
\hline & Least complex & $\begin{array}{l}\text { Somewhat } \\
\text { complex }\end{array}$ & More complex & Most complex \\
\hline $\begin{array}{l}\text { Considering } \\
\text { the meaning } \\
\text { of the data } \\
\text { representations }\end{array}$ & $\begin{array}{l}\text { Sudents are } \\
\text { provided with } \\
\text { a formatted } \\
\text { data table and } \\
\text { do not consider } \\
\text { meaningful } \\
\text { representation } \\
\text { of data }\end{array}$ & $\begin{array}{l}\text { Students design } \\
\text { their own data } \\
\text { tables giving little } \\
\text { consideration to } \\
\text { the meaning of } \\
\text { representations } \\
\text { of data }\end{array}$ & $\begin{array}{l}\text { Students } \\
\text { represent data } \\
\text { in multiple ways } \\
\text { including tables, } \\
\text { drawings, graphs, } \\
\text { photographs, } \\
\text { or statistical } \\
\text { representations } \\
\text { with little } \\
\text { consideration of } \\
\text { the meaning of } \\
\text { representations }\end{array}$ & $\begin{array}{l}\text { Students represent data in multiple ways including } \\
\text { tables, drawings, graphs, photographs, or statistical } \\
\text { representations, thoughtfully considering the meaning } \\
\text { of representations }\end{array}$ \\
\hline $\begin{array}{l}\text { Communicating } \\
\text { and defending } \\
\text { findings }\end{array}$ & $\begin{array}{l}\text { Students do not } \\
\text { communicate } \\
\text { or defend their } \\
\text { findings either } \\
\text { orally or in } \\
\text { writing }\end{array}$ & $\begin{array}{l}\text { Students give } \\
\text { limited attention } \\
\text { to communicating } \\
\text { and defending } \\
\text { their findings } \\
\text { orally or in } \\
\text { writing }\end{array}$ & $\begin{array}{l}\text { Students } \\
\text { communicate } \\
\text { their findings } \\
\text { orally or in } \\
\text { writing with } \\
\text { some emphasis } \\
\text { on defending } \\
\text { their findings }\end{array}$ & $\begin{array}{l}\text { Students communicate their findings orally or in } \\
\text { writing. Students use logical arguments to defend their } \\
\text { findings }\end{array}$ \\
\hline $\begin{array}{l}\text { Connecting data } \\
\text { to scientific } \\
\text { concepts }\end{array}$ & $\begin{array}{l}\text { Students do } \\
\text { not connect } \\
\text { data to research } \\
\text { questions }\end{array}$ & $\begin{array}{l}\text { Students use their } \\
\text { data to answer } \\
\text { questions other } \\
\text { than the primary } \\
\text { research question }\end{array}$ & $\begin{array}{l}\text { Students use } \\
\text { different forms } \\
\text { of reasoning. } \\
\text { (c.g., contrastive, } \\
\text { deductive, } \\
\text { inductive) to } \\
\text { connect data } \\
\text { to the primary } \\
\text { research } \\
\text { question. } \\
\text { Reasoning } \\
\text { may require } \\
\text { inferences } \\
\text { involving } \\
\text { several layers of } \\
\text { connections }\end{array}$ & $\begin{array}{l}\text { Students use results from different studies, as well } \\
\text { as different forms of reasoning (e.g., contrastive, } \\
\text { deductive, inductive) to connect their data to the } \\
\text { primary research question. The reasoning may require } \\
\text { inferences involving several layers of connections }\end{array}$ \\
\hline $\begin{array}{l}\text { Generating } \\
\text { questions }\end{array}$ & $\begin{array}{l}\text { The overarching } \\
\text { research } \\
\text { question is } \\
\text { provided; } \\
\text { students do } \\
\text { not generate or } \\
\text { explore other } \\
\text { questions during } \\
\text { the inquiry }\end{array}$ & $\begin{array}{l}\text { The overarching } \\
\text { research question } \\
\text { is provided; } \\
\text { students } \\
\text { generate and/ } \\
\text { or explore other } \\
\text { questions based } \\
\text { on observations } \\
\text { during inquiry }\end{array}$ & $\begin{array}{l}\text { The overarching } \\
\text { research } \\
\text { questions is } \\
\text { provided: } \\
\text { students generate } \\
\text { and/or explore } \\
\text { other questions } \\
\text { based on } \\
\text { observations and } \\
\text { wider exploration } \\
\text { of the research } \\
\text { topic during the } \\
\text { inquiry }\end{array}$ & $\begin{array}{l}\text { Students generate their own research question; } \\
\text { other questions are generated and explored based on } \\
\text { observations and wider exploration of the research } \\
\text { topic during the inquiry }\end{array}$ \\
\hline
\end{tabular}


Table 4. Levels of proficiency in data collection and representation shown in written documents

\begin{tabular}{|l|c|c|c|}
\hline & $\begin{array}{c}\text { Produced complete data } \\
\text { table }\end{array}$ & $\begin{array}{c}\text { Accurate mathematical } \\
\text { calculations }\end{array}$ & $\begin{array}{c}\text { Appropriate graph with } \\
\text { proper x, } \mathbf{y} \text {-axes }\end{array}$ \\
\hline Season I $(\mathrm{n}=35)$ & $80 \%$ & $\mathrm{n} / \mathrm{a}$ & $66 \%$ \\
\hline Season II $(\mathrm{n}=30)$ & $67 \%$ & $\mathrm{n} / \mathrm{a}$ & $73 \%$ \\
\hline UVB $(\mathrm{n}=30)$ & $97 \%$ & $37 \%$ & $77 \%$ \\
\hline Air Pollution $(\mathrm{n}=30)$ & $90 \%$ & $83 \%$ & $77 \%$ \\
\hline Relative Humidity $(\mathrm{n}=29)$ & $100 \%$ & $80 \%$ & $97 \%$ \\
\hline
\end{tabular}

\section{What Categories Of complex Reasoning were Displayed in Girls' Interpretations of Data Collected During Technology-Enhanced Inquiry? Did the Categories of Complex Reasoning Change Over Subsequent Encounters with Technology? If so, how?}

Considering the meaning of the representations of data. The girls' graphic representations and considerations of their meaning exhibited modest increase in complexity over time. Graphic representations became more independently created, accurate, and varied. Students increased the variations used in their graphic representations as a result of following scaffolds to use different graphic representations to communicate data in different ways. However, girls would commonly copy directly what they saw presented on the calculator screen (see middle image in Figure 1), without adding information that would make the graphic comprehensible. Or, they included several representations without connecting them or offering meaning for why they illustrated the data they did.

Figure 1. A student's multiple representations of data collected in an inquiry experience illustrating a model of seasonal temperature and light changes. The image on the left is a table which was provided to the students to input their predictions and actual light and heat measurements. The image in the middle is a student's drawing of what she saw on the calculator screen. The image to the right is a student 's graph representing light data she recorded.

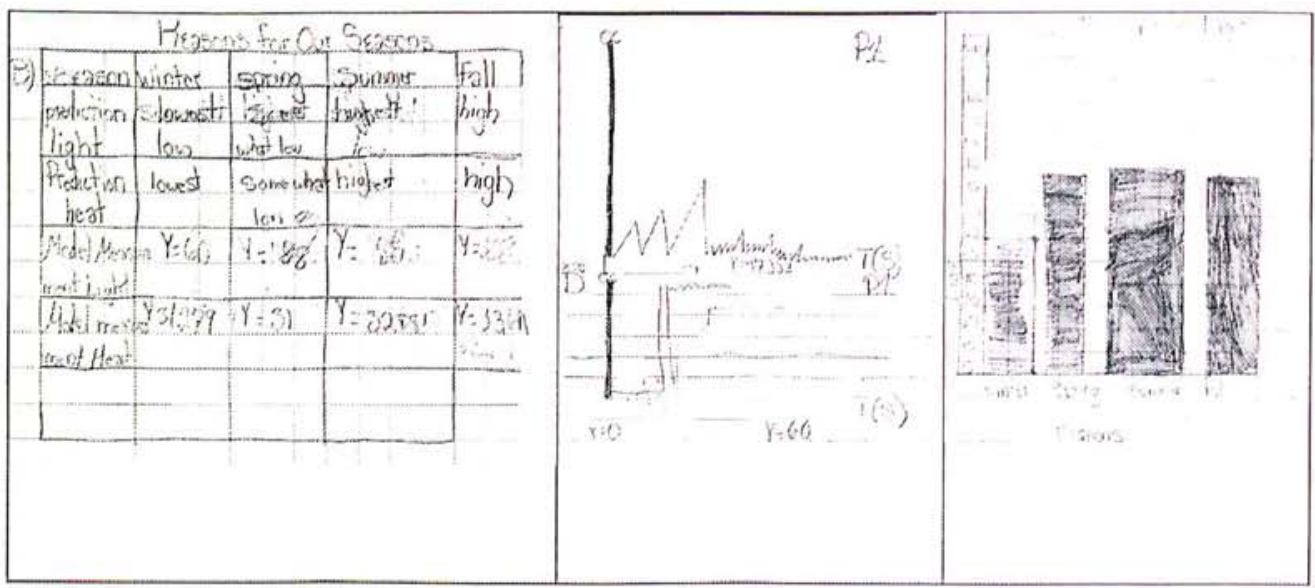


Towards the end of the study period, the girls consistently submitted graphs such as that displayed in Figure 2. Over time, the girls became more adept, though not fully proficient, at labeling their graphs. They also illustrated data on their graphs with greater accuracy. Figures 2 and 3 illustrate one girl's graphs at three points in the case study period. They show characteristic growth and change in graphic representation skill. The graphic representations in Figure 2 are from an inquiry experience at a mid-point in the case study period. The numerical labeling on units does not represent comprehensible information, creating graphs that lack desired meaning. They are also missing labels and data points. Figure 3 shows a graphic representation from the last inquiry experience in the case study period. It is a more accurate and meaningful representation, with clear labels and numerically correct spacing of units. Still, graphs such as this one lack some important labels, such as units for light measurements, and are not arranged in a way that optimally illustrates the meaning of the findings.

Figure 2. A students' graphic representations of data from the middle of the case study period

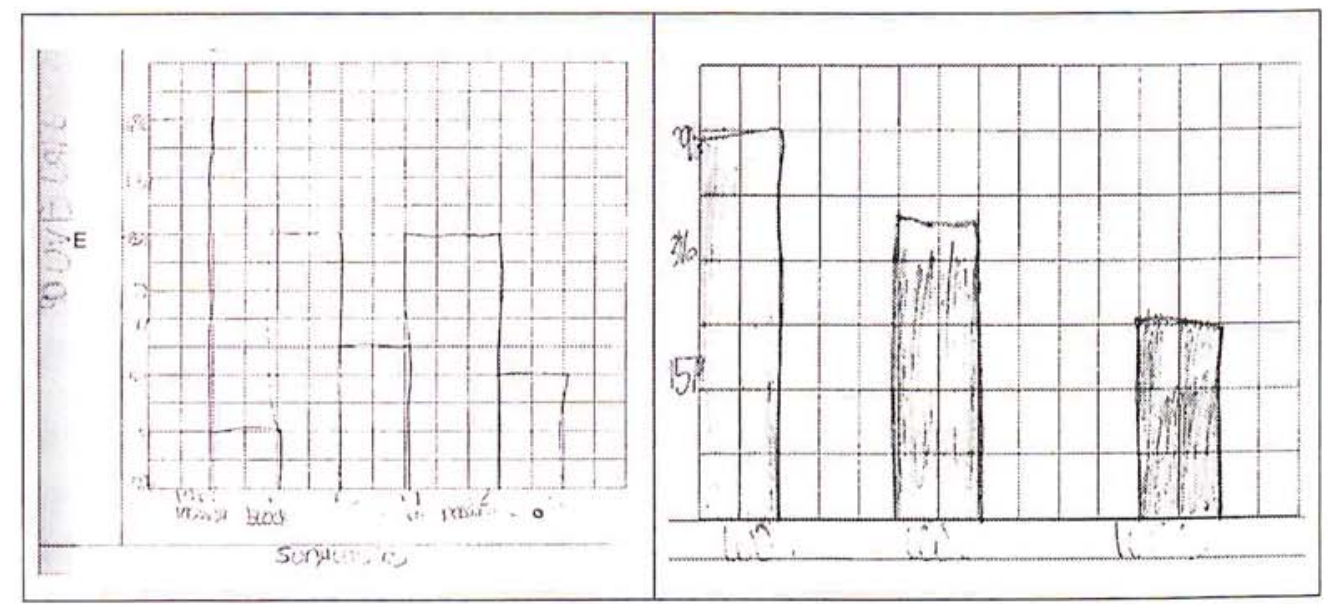

Figure 3. A student's graphic representation of relative humidity data from the end of the case study period

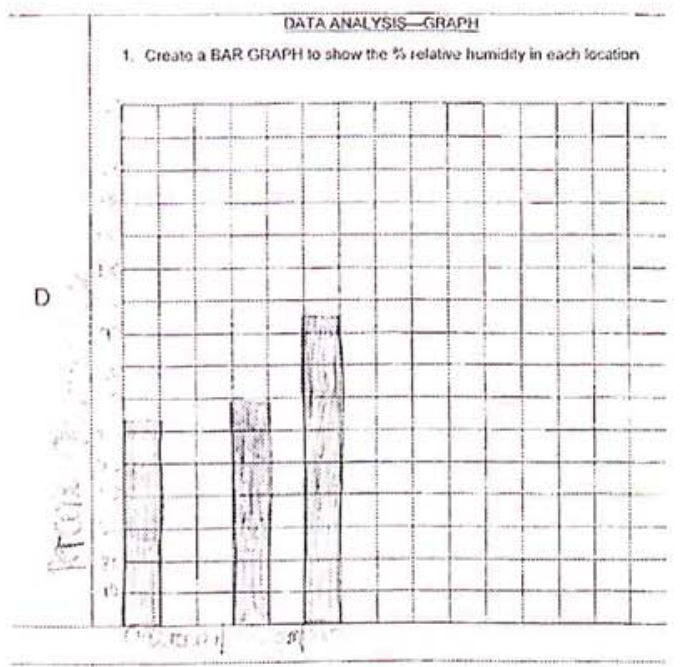


To a great extent, many inaccuracies persisted in students' graphic representations throughout the case study period. There are a few possible explanations for these inaccuracies. The girls may not fully consider graphic representations as a means for displaying their findings. They also may simply have not fully developed the skills for graphing, or the understanding that graphing is a way to model findings and communicate them. Also, the standards and concepts around graphing may not have been clearly communicated to the girls.

Communicating and defending findings. Most often, students communicated their findings orally or in writing, but did not draw on specific data or use logical arguments to defend them. When the girls were asked to use examples from their investigations to explain why there are seasons, they either provided specific data points, or explained by talking through the investigation, but not both. One student said,

I learned that with the globe and the temperature and the light, you tilt it over and the season for the winter, or fall, or spring or whatever. Whatever temperature it is tells us what season it is. For example, put the temperature probe on the globe... you tilt it over a little bit, and then the temperature comes up as 92. And then if you tilt it back, from the right, then it will be like, 20... (interview, 3-17-10)

This student offered specific data, but did not explain it. Another girl said,

Well, the Earth is tilted as it moves towards the Sun... We found that if you tilted it more, it 's more sumny... And if you tilt it a little bit back it's Spring, and sometimes Fall, but if you tilt it all the way back, where it's not getting direct sunlight, it's going to get indirect Sun and it's going to be winter... I noticed with the temperature it would get lower [in indirect light]. It could because direct sunlight produces more heat than indirect sunlight. (interview, 3-17-10)

This student did not offer specific data, yet did have a more rich explanation for the phenomenon. In this technology-enhanced inquiry experience, the student exhibited increasing complexity in communicating and defending findings, as she used her experiences and data to defend conclusions. Complexity in communicating and defending findings increased over time.

Connecting data to scientific concepts. In some respects, the connections students made to scientific concepts exhibited the greatest gains in complexity. Towards the beginning of the case study period, very few connections were made between data and scientific concepts. Typically, the girls either explained in narrative form the data they showed in their graphic representation, or they offered explanations of the scientific concepts that were similar to what they had read in their science textbooks. Across the lessons, the girls increasingly linked data to scientific concepts. However, such connections remained superficial. For example, after an inquiry experience using dry and wet temperature probes to find relative humidity in several sites in and around their school, the girls were asked to describe the sites which had the lowest and highest relative humidity, and provide reasoning for their findings. The following students' written response typifies the responses students offered:

The wet temperature was always lower than the dry temperature. The classroom / had the lowest relative humidity/ because the classroom has a warm temperature. Outside / had the highest relative humidity/ because outside it was cold and just got finish/ed/ raining. (artifact, 5-7-1()) 
Figure 4. Students' questions generated during technology-enhanced inquiry

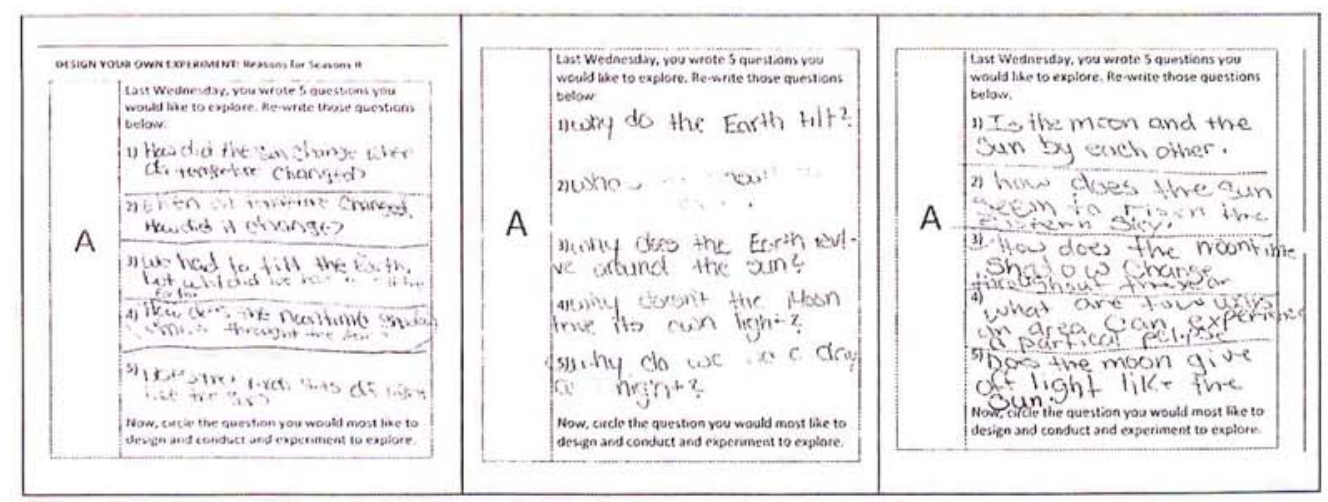

Although this student offered no specific data points, and only made simple connections to scientific concepts, the effort to link data to scientific concept was evident.

Generating questions. Three factors influenced the girls' complexity of reasoning as it relates to generating new questions: 1) flexibility in the inquiry task structure, 2) opportunities for peer interaction, and 3) encouragement from the teacher. After the second inquiry experience, students were tasked with generating new questions to explore in writing, such as those in Figure 4. In this case, they were explicitly prompted to devise questions to be investigated in the third inquiry experience. Based on the modified version of Dolan and Grady's (2010) matrix, these questions mostly demonstrated somewhat complex reasoning, with some more complex reasoning. These questions contain elements of being investigable, an aspect of more complex reasoning.

In the second inquiry experience the girls generated their own research questions, and in the third inquiry experience, girls had opportunities to revise, select, and design experiments to explore these questions with their peers. During opportunities for peer interaction, where the girls generated questions informally, they exhibited more complex reasoning as indicated in Table 2. For example, at the end of one of the investigations modeling seasonal changes in light and temperature, one group had the following interaction:

S1: /operates the graphing calculator in a way to show the data differently/

S2: loverlooking SI's shoulder/I didn't even know you could do that.

S1: What are the values, so that I can put them in my table?

S2: 540 and 541 .

S1: Ugh. Sheesh.

S2: Let's try somewhere on the Southern Hemisphere now.

SI: I'm gonna look at Colombia. Right there Ipointing to Colombia on the globel.

This pair of students moved beyond modeling seasonal changes in the Northern Hemisphere to experimenting with such changes in a different geographic location. They were offered ample time with each other to generate and try new investigations which stemmed from, but moved beyond, the original assignment. 
The following example from observations of a focus group illustrates encouragement from the teacher during technology-enhanced inquiry experiences:

S1: /To teacher, pointing to her group member/ Tell her this is a good question. I wonder if we do summer twice, will we get the numbers changed?

T: Ok, so you're talking about doing repeats. What do you think of that question? ...here's what I want you to think about. You know the equipment that we've been using, right? Which one could you use to design an experiment to do? If you want to alter it a little bit you can do that. Like, if you want to add something in there, you can do that. Maybe you want to do it three times, or maybe you want to do something different.

S2: That would be too much work! Oh, I want to do that one... I points to another student 's paper)

T: Yeah, you might have to revise it a little, but yeah, you could do that. So, start thinking about what you could do, because you're gonna want to get a lot of data, right? To be able to say, is it the same. And what might make it change? Start thinking about that. But I like that, that's a great question!' Ito SI, then turns to S3I I like yours too, just so you know.

S1: See? We can do it again...or we could do yours / referencing S3's question/. (classroom observation, 3-26-10)

Of note in this interaction is the encouragement offered by the teacher. Even in earlier teacher prompting for question generation, the girls exhibited greater complexity in reasoning when instruction moved beyond written prompts to verbal encouragement from the teacher.

Complex reasoning changed over subsequent encounters with technology. Across the four cognitive processes analyzed, the girls exhibited increases in their complexity of reasoning, some more modestly than others. Table 5 offers calculated percentages of responses exhibiting varying levels of complexity. Most responses analyzed showed more than one level of complexity, resulting in total percentages higher than $100 \%$. Of particular note is the considerable drop in least complex responses for Lesson 4. Also, the percentage of responses in the somewhat complex category increased to $100 \%$ by the end of the case study period. However, no responses analyzed exhibited most complex reasoning.

\section{DISCUSSION AND IMPLICATIONS}

Increasingly, K-12 students are being asked to perform at high levels of complex reasoning in science classrooms. This process involves learning experiences that include using data collection technologies

Table 5. Percentage of written responses exhibiting varying levels of complexity

\begin{tabular}{|l|c|c|c|c|}
\hline \multicolumn{1}{|c|}{ Complexity of reasoning } & Least complex & Somewhat complex & More complex & Most complex \\
\hline Temperature & $44 \%$ & $65 \%$ & $19 \%$ & $0 \%$ \\
\hline Seasons I \& II & $42 \%$ & $78 \%$ & $32 \%$ & $0 \%$ \\
\hline UVB & $29 \%$ & $82 \%$ & $43 \%$ & $0 \%$ \\
\hline Air Pollution & $40 \%$ & $83 \%$ & $43 \%$ & $0 \%$ \\
\hline Relative Humidity & $38 \%$ & $100 \%$ & $31 \%$ & $0 \%$ \\
\hline
\end{tabular}


to collect and analyze data, interpreting results, and constructing scientific explanations. Unfortunately, the situation in schools with high percentages of Black girls has not traditionally provided experiences in these areas. This study provided an opportunity for us to collaborate with urban teachers to develop and implement instructional experiences that would further foster Black girls' abilities to engage in technology-enhanced scientific inquiry. As we review the findings in regards to generating, representing and interpreting data, we can see that our attempts fostered an improvement. We must, however, continue to seek a higher degree of reasoning from students about the data. To that end, we now turn our attention back to our own pedagogy.

Across the technology-enhanced inquiry lessons, girls increasingly used technology proficiently, and made positive progress towards proficiency in their graphic representations of data. These findings are reflective of some studies of technology-enhanced inquiry (e.g., Lee et al., 2010; Parr et al., 2004). In general, our series of technology-enhanced inquiry-based activities were associated with an increase in the girls' ability to organize and represent data appropriately, as is similar to the findings of Kwon's (2002) study. However, with regard to our efforts to increase the girls' abilities to reason and interpret the data accurately, our findings were mixed, much as in some studies in science courses with a strong emphasis on mathematical reasoning (Mitchemore \& Cavanagh, 2000; Harskam et al., 2000). Perhaps, then, technology-enhanced inquiry has a greater impact on conceptual reasoning than it does complex reasoning about data. During the study, we observed many girls did not use data collected from their inquiry investigations, either partially or extensively, to reason about scientific phenomena.

Working within this urban classroom has afforded us new insights with regard to our overall goals. Such insights include the need of a longitudinal approach to fostering inquiry practices and an explicit structuring and scaffolding approach to guiding the girls to reason through the inquiry process. We believe that a longitudinal approach that would afford us more time to scaffold the process is necessary given the limited prior inquiry experiences of the girls and teachers, as well as the authoritative context. In regards to the later, Delpit (1995) cautioned against dismissing such issues of power in the school setting; in this case, the teacher-centered approach to teaching and learning. Although this has been found to be a consideration in many schools, it is particularly evident in urban schools (Songer, et al., 2002; Barton, 2007; Kahle, Meece \& Scantlebury, 2000). We suggest the solution to this climate must lie with the urban teachers. Our future professional development opportunities need to illustrate to the teachers how to redirect ownership of the learning process by students through constructive formative dialogues. Furthermore, we now realize that teachers' potential for scaffolding the girls' reasoning abilities was never fully realized due the limited use of constructive feedback, which we contend is necessary to guide the girls' reasoning skills.

Although prior studies indicate elementary students are capable of pursuing significant, productive explorations, which result in complex reasoning about data and its relationship to science concepts (Songer \& Gotwals, 20()4; Tytler \& Peterson, 2003), our initial findings in regards to highlighting these capabilities of urban elementary Black girls are mixed. We posit that a combination of factors including school climate and the types of scaffolding contributed to low levels of reasoning displayed in their written documents. It is these considerations we take with us as we further seek to address the gap between the classroom experience provided in our urban schools and Black girls' potential competencies. 
Examining the Levels of Reasoning Used by Urban Elementary Black Girls

\section{FUTURE RESEARCH DIRECTIONS}

In terms of enhancing urban elementary Black girls' efforts in collecting and analyzing data, as well as generating arguments and explanations as they engage in technology-enhanced inquiry, our research demonstrated that a short-term collaboration was associated with modest improvements in the girls' ability to engage in complex reasoning. Although our collaboration with teachers at this school was only four months long and included six technology-enhanced inquiry lessons, the progress made by the girls raises questions about the levels of reasoning that could have been achieved with a more long-term intervention with systemic professional development with teachers. Our research also raises further questions about advancing the success of these young women. As noted, studies have shown that scaffolding is needed to engage students in increasingly higher levels of reasoning. We understood this as we began this process; but the extent and duration of scaffolding appears to be greater than what we anticipated. Throughout the process, our collaborative group utilized formative assessment strategies. In our future efforts, we intend to explore ways to better scaffold the process - specifically formative dialogues. We question whether student-teacher dialogues will provide the needed opportunities for teachers to identify reasoning and respond in a manner that encourages further progress. We believe this is critical as our findings also revealed that we attempted to move from scaffolding the first few activities and reach full inquiry too quickly. This, of course, raises further questions about the level of professional development and support, for teachers and students, needed to foster such dialogues in underserved schools.

\section{CONCLUSION}

This inquiry came out of our efforts to establish an effective STEM learning environment for elementary Black girls. We sought to understand the influence of technology-enhanced data collection on learning, specifically girls' abilities to collect and analyze data, and generate explanations as they engaged in technology-enhanced inquiry. The technology-enhanced inquiry experiences were associated with modest gains in complex reasoning over the four-month period study period. The girls became more proficient at labeling their graphs and illustrating data, making connections between the data and science content, and explaining the phenomenon. They did not, however, become fully proficient at using graphic representations to communicate results. On occasion they generated their own graphic representations, but more often they copied directly from the calculator screen. Also, while on occasion their reasoning about data was rich and complex, often they did not adequately elaborate or of fer necessary explanations.

If we are to support efforts to close the achievement gap for Black girls, we must continue to carefully monitor these experiences. This process must continue to focus on uncovering whether our approach to integrating these technologies into the learning environment leads to the desired student outcomes; however, we believe our focus must expand beyond the experiences of the classrooms. If we are to understand whether we are truly preparing these teachers to meet the needs of youth populations underserved in science education, we must include the learning experiences of students from underserved populations. These future inquiries must continue to inform our practice. 
Examining the Levels of Reasoning Used by Urban Elementary Black Girls

\section{REFERENCES}

American Association of University Women Educational Foundation. (1999). Gender gaps: Where schools still fail our children. New York: Marlowe \& Company.

Ary, D., Jacobs, L. C., Razavieh, A., \& Sorensen, C. (2006). Introduction to Research in Education (7th ed.). Belmont, CA: Thomson Wadsworth.

Barton, A. C. (2007). Science learning in urban settings. In S. K. Abell \& N. G. Lederman (Eds.), Handbook of research on science education (pp. 319-343). Mahwah, NJ: Lawrence Erlbaum Associates, Inc.

Bencze, J. L., \& Bowen, G. M. (2007). Student-teachers' dialectically developed motivation for promoting student-led science projects. International Journal of Science and Mathematics Education, 7(1), 133-159. doi:10.1007/s10763-(0)7-9115-6

Bowen, G. M., \& Roth, W.-M. (20)3). Graph interpretation practices of science and education majors. Canadian Journal of Science. Mathematics and Technology Education, 3(4), 498-512. doi:10.1(08()/14926150309556585

Bowen, G. M., \& Roth, W.-M. (2005). Data and graph interpretation practices among preservice science teachers. Journal of Research in Science Teaching, 42(10), 1063-1088. doi:10.1002/tea.20086

Brickhouse, N. W., Lowery, P., \& Schultz, K. (2000). What kind of girl does science? The construction of school science identities. Journal of Research in Science Teaching, 37(5), 441-458. doi:10.1002/ (SICI) 1098-2736(200005) 37:5<441::AID-TEA4>3.0.CO;2-3

Campbell, T., Longhurst, M., Wang, S.-K., Hsu, H.-Y., \& Coster, D. (2015). Technologies and reformbased science instruction: The examination of a professional development model focused on supporting science teaching and learning with technologies. Journal of Science Education and Technology, 24(5), 562-579. doi:10.1007/s10956-015-9548-6

Carlone, H. B. (2004). The cultural production of science in reform-based physics: Girls' access, participation and resistance. Journal of Research in Science Teaching, 4l(4), 392-414. doi:10.1002/tea.20006

Chavous, T., Rivas-Drake, D., Smalls, C., Griffin, T., \& Cogburn, C. (2008). Gender matters, too: The influences of school racial discrimination and social identity on academic engagement outcomes among African American adolescents. Developmental Psychology, 44(3), 637-654. doi:10.1037/00121649.44.3.637 PMID: 18473633

Chinn, C. A., \& Malhotra, B. M. (2002). Epistemologically authentic inquiry in schools: A theoretical framework for evaluating inquiry tasks. Science Education, 86(2), 175-218. doi:10.1002/sce.10001

Creswell, J. (1998). Qualitative inquiry and research design: Choosing among five traditions. Thousand Oaks, CA: Sage.

Creswell, J. (2002). Educational research: Planning, conducting, and evaluating quantitative and qualitative research. Upper Saddle River, NJ: Pearson Education. 
Dolan, E., \& Grady, J. (2010). Recognizing students' scientific reasoning: A tool for categorizing complexity of reasoning during teaching by inquiry. Journal of Science Teacher Education, 2l(1), 31-55. doi:10.1007/s10972-009-9154-7 PMID:21113314

Economics and Statistics Adminstiration. (2011). Women in STEM: A gender gap innovation. Washington, DC: U.S. Department of Commerce. Retrieved December 11, 2014 from http://www.esa.doc.gov/ Reports/women-stem-gender-gap-innovation

Fordham, S. (1993). "Those loud black girls": (Black) women, silence, and gender "passing" in the academy. Anthropology \& Education Quarterly, 24(1), 3-32. doi:10.1525/aeq.1993.24.1.05x1736t

Forgasz, H. J., Vale, C., \& Ursini, S. (2010). Technology for mathematics education: Equity, access and agency. In C. Hoyles \& J.-B. Lagrange (Eds.), Mathematics Education and Technology-Rethinking the Terrain (pp. 385-403). New York: Springer.

Harskamp, E., Suhre, C., \& Van Streun, A. (2000). The graphics calculator and students' solution strategies. Mathematics Education Research Journal, 12(1), 37-52. doi:10.1007/BF(03217073

Johnson, R., DeMoss, G. S., \& Sorensen, R. (2003). Earth science with Vernier. Beaverton, OR: Vernier Software and Technology.

Kahle, J., Meece, J., \& Scantlebury, K. (2000). Urban African-American middle school students: Does standards-based teaching make a difference? Journal of Research in Science Teaching, 37(9), 1019-1041. doi:10.1002/1098-2736(200011)37:9<1019::AID-TEA9>3.0.CO;2-J

Kastberg, S., \& Leatham, K. (2005). Research on graphing calculators at the secondary level: Implications for mathematics teacher education. Contemporary Issues in Technology \& Teacher Education, $5(1), 25-37$.

Keeley, P., Eberle, F., Farrin, L., \& Oliver, L. (2005). Uncovering student ideas in science: Vol. 1. 25 formative assessment probes. Alexandria, VA: NSTA Press.

Krajcik, J., Marx, R., Blumenfeld, P., Soloway, E., \& Fishman, B. (2000). Inquiry based science supported by technology: Achievement among urban middle school students. Washington, DC: National Science Education Standards. (ERIC Document Reproduction Service No. ED443676).

Kwon, O. N. (2002). The effect of calculator-based ranger activities on students' graphing ability. School Science and Mathematics, 102(2), 57-67. doi:10.1111/j.1949-8594.20()2.tb17895.x

Lee, H.-S., Linn, M. C., Varma, K., \& Liu, O. L. (2010). How do technology-enhanced inquiry science units impact classroom learning? Journal of Research in Science Teaching, 47(1), 71-90. doi:10.1002/ tea. 20304

Lee, H.-S., \& Songer, N. B. (2003). Making authentic science accessible to students. International Journal of Science Education, 25(8), 923-948. doi:10.1080/095(0)690305023

Linn, M. (2003). Technology and science education: Starting points, research programs, and trends.'. International Journal of Science Education, 25(6), 727-758. doi:10.1(08()/(095(0)690)3(05017 
McKenzie, D. L., \& Padilla, M. J. (1986). The construction and validation of the test of graphing in science (TOGS). Journal of Research in Science Teaching, 23(7), 571-579. doi:10.10(02/tea.36602307(02

Mitchelmore, M., \& Cavanagh, M. (2000). Students' difficulties in operating a graphics calculator. Mathematics Education Research Journal, I2(3), 254-268. doi:10.1007/BF03217088

National Governors Association Center for Best Practices (NGACBP). (2010). Common Core State Standards for mathematics. Retrieved from: http://www.corestandards.org/ Math/

National Research Council. (2012). A framework for K-I2 science education: Practices, crosscutting concepts and core ideas. Washington, DC: National Academies Press.

NGSS Lead States. (2013). Next generation science standards. Retrieved from: http://www.nextgenscience.org/

Parr, C. S., Jones, T., \& Songer, N. B. (2004). Evaluation of a handheld data collection interface for science learning. Journal of Science Education and Technology, 13(2), 233-242. doi:10.1023/ B:JOST.00(0)(31262.22712.e0

Pringle, R. M., Brkich, K. M., Adams, T. L., West-Olatunii, C., \& Archer-Banks, D. A. (2012). Factors influencing elementary teachers' positioning of African American girls as science and mathematics learners. School Science and Mathematics, 112(4), 217-229. doi:10.1111/j.1949-8594.2012.00137.x

Rollock, N. (2007). Why Black girls don't matter: Deconstructing gendered and racialised discourses of academic success in an inner city school. British Journal of Learning Support, 22(4), 197-202. doi:10.1111/j.1467-96(04.2007.0(0471.x

Roth, W.-M. (1996). Where is the context in contextual word problems?: Mathematical practices and products in grade 8 students' answers to story problems. Cognition and Instruction, 14(4), 487-527. doi:10.12(07/s1532690xci1404_3

Roth, W.-M., McGinn, M. K., \& Bowen, G. M. (1998). How prepared are preservice teachers to teach scientific inquiry? Levels of performance in scientific representation practices. Journal of Science Teacher Education, 9(1), 25-48. doi:10.1(023/A:10(29465505918

Smith-Evans, L., \& George, J. (2014). Unlocking opportunity for African American girls: A call to action for educational equity. New York: The NAACP Legal Defense and Educational Fund and The National Women's Law Center. Retrieved December 11, 2014 from http://www.nwlc.org/resource/unlockingopportunity-african-american-girls-call-action-educational-equity

Songer, N. B. (20)(0). Persistence of inquiry: Evidence of complex reasoning among inner city middle school students. Paper presented at the Annual Meeting of the American Educational Research Association, San Diego, CA.

Songer, N. B., \& Gotwals, A. W. (2004). What constitutes evidence of complex reasoning in science? Paper presented at the 6th International Conference on Learning Sciences, Santa Monica, California.

Songer, N. B., Kelcey, B., \& Gotwals, A. W. (2009). How and when does complex reasoning occur? Empirically driven development of a learning progression focused on complex reasoning about biodiversity. Journal of Research in Science Teaching, 46(6), 610-631. doi:10.1002/tea.20313 
Songer, N. B., Lee, H.-S., \& Kam, R. (2002). Technology-rich inquiry science in urban classrooms: What are the barriers to inquiry pedagogy? Journal of Research in Science Teaching, 39(2), 128-150. doi:10.1002/tea.10013

Stake, R. (1995). The art of case study research. Thousand Oaks, CA: Sage.

Stemler, S. (2001). An overview of content analysis. Practical Assessment, Research \& Evaluation, 7(17). Retrieved from http://PAREonline.net/getvn.asp?v=7\&n=17

Tal, T., Krajcik, J., \& Blumenfeld, P. C. (2006). Urban schools' teachers enacting project-based science. Journal of Research in Science Teaching, 43(7), 722-745. doi:10.1002/tea.201(02

Texas Instruments. (2011). CBL2. Retrieved July 18,2011 from http://education.ti.com/educationportal/ sites/US/productDetail/us_cbl_2.html

Thornton, R. K. (2008). Effective learning environments for computer supported instruction in the physics classroom and laboratory. In M. Vicentini \& E. Sassi (Eds.), Connecting research in physics education with teacher education. International Commission on Physics Education. Retrieved December 15, 2014 from vnr.st/sb4b

Tytler, R., \& Peterson, S. (2003). Tracing young children's scientific reasoning. Research in Science Education, 33(4), 433-465. doi:10.1023/B:RISE.0000005250.04426.67

Volz, D. L. (2000). Middle school science with calculators: Science experiments using Vernier sensors with the LabPro or the CBL 2 interface. Beaverton, OR: Vernier Software and Technology.

Webb, M. (2008). Impact of IT on science education. In J. Voogt \& G. Knezek (Eds.), International handbook of information technology in primary and secondary education (pp. 133-148). Springer International Handbooks of Education, Volume 20. Springer. doi:10.1007/978-0-387-73315-9_8

Weber, R. P. (1990). Basic Content Analysis (2nd ed.). Newbury Park, CA.

Wilson, C., Taylor, J., Kowalski, S., \& Carlson, J. (2010). The relative effects and equity of inquiry-based and commonplace science teaching on students' knowledge, reasoning, and argumentation. Journal of Research in Science Teaching, 47(3), 276-301.

Wu, H.-K., \& Krajcik, J. S. (2006). Inscriptional practices in two inquiry-based classrooms: A case study of seventh graders' use of data tables and graphs. Journal of Research in Science Teaching, 43(1), 63-95. doi:10.1002/tea.20092

Zucker, A. A., Tinker, R., Staudt, C., Mansfiled, A., \& Metcalf, S. (2008). Learning science in grades 3-8 using probeware and computers: Findings from the TEEMSS II project. Journal of Science Education and Technology, 17(1), 42-48. doi:10.1007/s10956-007-9086-y

\section{KEY TERMS AND DEFINITIONS}

Complex Scientific Reasoning: The ability to analyze and interpret empirical data and formulate explanations from evidence. 
Probeware: Scientific equipment, interfaced with software and computers, which allows data to be collected, interpreted and analyzed.

Scientific Argumentation: A rebuttal to a scientific claim, pointing to a weakness in the evidence or providing other evidence that counters the claim.

Scientific Explanations: Scientific claims, based on observable evidence that is sufficiently justified as relevant to the claim. They are developed in an attempt to capture the best understanding of the natural world.

Scientific Inquiry: The process through which people develop knowledge and understandings of the natural world.

Technology-Enhanced Instruction: The integration of technology into the learning process in order to provide a higher quality learning experience. 